\title{
Памяти чекистов Алдана
}

\author{
Петраков С.П., студент, \\ ГАПОУ РС (Я) «Алданский политехнический техникум», \\ 2. Алдан

\section{Научный руководитель: преподаватель Пахомова О.Г.}

Многие века создавалась история. Великие люди творили нашу жизнь. И каждый ее момент возможен только потому, что были предыдущие столетия. Об этом мы должны постоянно помнить, это мы должны осознавать, чтобы продолжать жить и оставаться при этом полноценным человеком - связующим звеном в непрерывном потоке времени. Д. С. Лихачев писал: «Память противостоит уничтожающей силе времени. Память - преодоление времени, преодоление пространства. Память - основа совести и нравственности, память - основа культуры. Хранить память, беречь память - это наш нравственный долг перед самим собой и перед потомками. Память - наше богатство».

Сегодня формирование ценностного отношения к историческому прошлому приобретает особую актуальность. Поколение молодых людей мало знает об истории города, района: о работе чекистов на территории Алданского района, о борьбе с бандитскими группировками, о грабежах и убийствах старателей, о вооруженных нападениях на сотрудников ОГПУ, о боевых операциях чекистов по ликвидации банд.

Цель: исследование и систематизация материала о деятельности сотрудников ЧК в Алданском районе.

\section{Для достижения цели поставлены следующие задачи:}

1. Розыск и интервьюирование родственников, получение информации из личного архива семьи чекиста.

2. Сбор, изучение и систематизация материалов по теме исследования.

3. Социологический опрос студентов АПТ и анализ результатов опроса.

4. Привлечение интереса молодежи к изучению истории малой родины через судьбы земляков.

Объект исследования: исторические события становления ЧК в Алданском районе.

Предмет исследования: биографии земляков - чекистов.

Метод: сбор информации, анализ, интервьюирование, систематизация архивных материалов.

Практическая значимость: данная работа может быть использована на уроках истории, классных часах в образовательных учреждениях города.

Было проведено исследование исторической осведомленности студенческой молодежи ГАПОУ РС (Я) «Алданского политехнического техникума» с целью выявления их знаний о деятельности ЧК, о чекистах. Было опрошено 54 студента вторых курсов:

1. Кто такие чекисты? Кого из чекистов Алдана вы знаете?

2. Что вы знаете о памятнике, расположенном на улице Горького,70?

3. В нашем городе есть переулок Чекистов, знаете ли вы почему он так называется? 
Результаты социологического исследования: ЧК».

На первый вопрос ответили: «не знаю» - 53 студента. 1 ответ - «это сотрудники

На второй вопрос 11 студентов ответили, что это памятник чекистам.

На третий вопрос ответили: «не знаю» - 54 студента.

Результаты исследования подтверждают, что тема работы выбрана актуально.

В настоящее время в Алдане проживает внучка героя - чекиста Денисова Е.Н. Нам удалось розыскать ее и взять интервью. Елена Николаевна рассказала нам биографию своего деда, показала фотографии, материалы из личного архива семьи. Из воспоминаний Денисовой Елены Викторовны: «Мой дедушка Найденов Андрей Иванович родился в 1915 году в городе Ачинске Красноярского края. В 1933 году был призван в ряды Советской Армии. После службы в армии в 1936 году женился на моей бабушке Тамаре Никифоровне и вместе с ней из Ачинска приехал в Алдан. Дедушка устроился на работу в трест «Алданзолото» - рабочим. В 1939 году у них родился мой отец -Найденов Виктор Андреевич. В 1940 году дедушка перешел работать в Алдансую тюрьму надзирателем, в те годы эта должность называлась так. В 1941 году у них родилась дочь Найденова Галина Андреевна, т.е сестра моего папы, моя тетя. В конце 1941 года был создан в Алдане районный отдел НКВД ЯАССР. Тюрьма, где работал мой дедушка, относилась к районному отделу НКВД ЯАССР. В этом году ему было присвоено звание «младший сержант внутренней службы». Дедушке тогда было 27 лет, его «убили» и он не успел вырастить своих детей. Бабушка растила их одна. Они выросли хорошими людьми.

С октября 1945 года на территории Алданского округа и Учурского района действовала бандитская группировка, в состав которой входили беглецы из колоний и тюрем. Они вливались в группу под названием «Добровольное общество борьбы против проекта Конституции СССР» под руководством бандита Е.Н. Павлова, которые объединившись, нападали на золотоприемные пункты, грабили склады, магазины, нападали на оленеводов, угоняли оленей, отбирали оружие у жителей, поджигали радиостанции, терроризировали население.

11 января 1943 года находясь в составе опергруппы по ликвидации вооруженных бандитов в районе Учурских гор -помощник начальника Алданской тюрьмы Яковлев Иван Егорович, помощник оперуполномоченного Алданского окружного отдела Давыдов Дмитрий Иннокентьевич и мой дедушка Найденов Андрей Иванович, надзиратель внутренней тюрьмы, героически погибли в перестрелке с бандитами. К большому сожалению родных и близких героев Яковлева И.Е и Давыдова Д.И. по запросам найти не удалось. Когда их привезли в Алдан, всех троих хоронили из районного дома культуры, который 27 августа 1999 года сгорел, на этом месте сейчас стоит церковь. Казалось, все жители Алдана - столько было народу, пришли проводить их в последний путь, со слов моей бабушки, отдать им последние почести. Моему папе тогда было 4 года, а моей тети на тот момент 2 годика. Это все, что я знаю со слов моей бабушки.

Бабушки (мамы моего отца) Найденовой Тамары Никифоровны и ее детей (папы - Найденова Виктора Андреевича и тети - Найденовой Галины Андреевны уже давно нет в живых. Из всех остались я - внучка, моя сестра и моя мама (жена моего папы) Найденова Галина Ивановна. Мне очень хочется увековечить память этих героев, поставить памятник на городском кладбище, где они трое захоронены в братской могиле». 
В 2016 году было принято решение о возведении мемориала алданским чекистам. Студенты техникума под руководством мастера Репкина С.А. изготовили в мастерских вазу в виде боевого патрона с металлическими цветами для братской могилы героев.

22 июня 2016 года состоялось торжественное открытие памятника чекистам. На открытии памятника присутствовали студенты и преподаватели техникума.

Изучив, собранные материалы, были систематизированы исторические события деятельности ЧК на территории Алданского района, восстановлена биография героя - чекиста Найденова Андрея Ивановича. Это помогло расширить кругозор по истории родного края и города. Все собранные материала, фото из личного архива Денисовой Елены переданы в музей ГАПОУ РС (Я) «Алданского политехнического техникума». На торжественном открытии было принято решение взять шефство над братской могилой.

Историю своей родины необходимо изучать по судьбам людей, ведь историю делают люди. Именно в человеческих судьбах отражаются время и человек - его общественное положение и духовные качества. Наш долг сохранить имена, подвиги, знаменательные исторические события, нравственные ценности из поколения в поколение.

Список литературы:

1. Лихачев Д.С. Память истории священна /Д. Лихачев/ М., 1986.

2. Столярова И. Бандиты не ушли от возмездия / И. Столярова // Якутия. - 2004. - 8 мая. О работе чекистов Якутии в годы Великой Отечественной войны

3.Материалы архива МВД РС (Я): «Щит и меч. К 95 - летию органов безопасности в Якутии», «1945-2005. 60 - летию Великой Победы посвящается....ветеранам Алданского РОВД»

4. Материалы Алданского историко - краеведческого музея.

5. Личный архив Денисовой Е.В

6. Пензина Г. Переулок Чекистов: дом на костях// Вечерний Алдан.-2007.- 14 марта.- стр. 2

7. Павлюченко Л. Всегда на посту//По материалам Алданского историко краеведческого музея.

\title{
Проявления молодежного агрессивного радикализма и ксенофобии в Тындинском районе Амурской области
}

\author{
Петрова Ю., студентка, \\ БАмИЖТ - (ф) ДВГУПС в г. Тынде \\ E-mail: bamigt.makarov@mail.ru
}

Научный руководитель: к.п.н., доцент Макаров П.В.

Есть народная мудрость: «Камень рождает гору, лишний кусок снега лавину». Молодежный агрессивный радикализм является потенциалом будущего экстремизма, который может перерасти в массовый терроризм. Мы считаем, что для России он 